DOI: $10.1515 / \mathrm{abcsj}-2017-0015$

\title{
Gender on the Agenda
}

Heather Duerre Humann, Gender Bending Detective Fiction: A Critical Analysis of Selected Works (McFarland: 2017. Kindle Edition. ISBN 978-1-4766-2841-7)

Heather Duerre Humann, who has previously published on the portrayal of Domestic Abuse in the Novels of African American Women (McFarland, 2014), has turned her attention to the subject of gender and its subversion in contemporary crime fiction, in her 2017 book, Gender Bending Detective Fiction: A Critical Analysis of Selected Works. This fascinating study presents an overdue examination of the representation of gender in crime fiction, specifically focusing on the portrayal of the hitherto overlooked themes of cross-dressing and transgender and their gender-political dimensions.

Humann's book furthermore assesses the impact of feminism and gender theory on the depictions and representations of crime and detectives in $20^{\text {th }}$ and $21^{\text {st }}$ century crime fiction. Her examination of these preoccupations in crime fiction is timely, reflecting the rising awareness of the complexity of gender bending and transgender in our contemporary society, but also drawing attention to the ways in which these gender issues continue to be overlooked, problematic or surrounded by stigma. The innovative dimension of Humann's analysis, the focus on crossdressing and transgender, contributes fresh insights into crime fiction criticism. Furthermore, by 'bending' the genre, Humann suggests, contemporary crime fiction possesses the capacity to instigate and encourage social, cultural and literary change. Given that so much crime fiction examines the nature and function of crime as disruption, on individual, collective, and social levels, this in-depth study these forms of changes is timely indeed.

Gender Bending Detective Fiction: A Critical Analysis of Selected Works opens with a discussion of a film, not a novel - namely Brian De Palma's 1980 film Dressed to Kill. The most powerful moment in the film, Humann asserts, is the one that signals the focus on gender bending, 
With this compelling example, Humann opens the book and presents her main hypothesis for the book, namely that the texts analysed in Gender Bending Detective Fiction: A Critical Analysis of Selected Works sit within specific historical and cultural contexts, which lend themselves to differing treatment of the question of gender, and also present differing attitudes towards the possibility of its subversion. As Humann states in Chapter Three, examining the attitudes of the 1980s,

both the practice of cross-dressing and the presence of transgender individuals became much more visible, the majority of people in society still had little understanding of gender identities or gender expressions that do not fit the binary categories of male and female. (Kindle Locations 890892)

Humann argues that $20^{\text {th }}$ century films, such as De Palma's Dressed to Kill, present a particularly compelling site for the examination and treatment of social and cultural anxieties around transgender, but states that the roots for this investigation can be found in crime fiction.

The ten chapters in Humann's book examine a variety of subjects in connection with gender disruption. These include subjects such as crossdressing and transgender, and an analysis of these depictions in relation to the body, sexuality and criminality. Mid-century authors such as Mickey Spillane, Humann asserts, produced gender-critical representations as part of their crime fiction: "Beyond breaking these taboos, Spillane also broke new ground by the way that some of his detective novels played with gender (though they ultimately conformed to mid-twentieth century American mores about gender and gender roles)" (Kindle Locations 502503). These topics are furthermore related to investigations of the construction of deviance and criminality. Authors examined in these contexts include Sue Grafton, Ruth Rendell, P.D. James, and Mickey Spillane. Commenting on the problematic attitudes towards gender expressed in the 1970s in the social and cultural contexts that formed the background for Ruth Rendell's work, for example, Humann observes that:

From a contemporary vantage point, it may seem odd that feminists of that time period reflected the more widely held feelings of transphobia so common to that decade, since transphobia [...] has its roots in sexism. However, those attitudes were widely held during the 1970s (even by second-wave feminists) and they are accordingly reflected. (Kindle 
Locations 728-731)

For P.D. James' work, Humann contends, gender and pathology and are closely linked and depicted with a sense for their complexity (Kindle Locations 1210-1211). According to Humann, Val McDermid, on the other hand, "occupies a unique position, one from which she can critique gender roles, call attention to gender norms, heteronorms, and cisgenderism, and also question traditionally held views about femininity and masculinity" (Kindle Locations 1485-1487). As the book progresses, Humann examines recent $21^{\text {st }}$ Century novels by Renee James (a transgender author), Robert Galbraith (aka J.K. Rowling) and T.E. Wilson, exploring how representations of gender and transgender have changed and evolved in recent years' crime fiction.

Along with the investigation of the central themes of gender subversion, cross-dressing and transgender, Humann's book contextualises the discussion of wider cultural transphobic and/or homophobic attitudes prevalent at the time of the publication of some of these crime novels, which impacted on their representation of gender or suggested links between gender and deviance. Discussing Mark SaFranko's 2014 novel Suicide, Humann notes that, as well as reflecting post-9/11 anxieties, the author also "address[es] transgenderism and highlighting the rampant transphobia that still persists into the twenty-first century, The Suicide also deals with issues such as suicide, rape, domestic violence, stalking, and police brutality" (Kindle Locations 1958-1959).

Humann further discusses attitudes of ambivalence towards gender bending in crime fiction, leading to portrayals that associate crossdressing practices with deviance, or present other kinds of ambivalent or problematic attitudes. It would have been interesting to see the book's analysis extended to include crime fiction from other parts of the world, which might have yielded interesting additional perspectives. An examination of the impact of Nordic Noir, or postcolonial crime fiction, for example, could no doubt have produced material to expand on the compelling discussions already presented.

Humann's Gender Bending Detective Fiction: A Critical Analysis of Selected Works constitutes a welcome and original contribution to crime fiction criticism. The book's central idea that gender and its subversion is central to the evolution of crime fiction in the present-day 
period is persuasive, and borne out by the textual evidence readily assembled from across its selection of popular crime fiction.

CHARLOTTE BEYER, University of Gloucestershire 